Jurnal Keperawatan Suaka Insan| Volume 5 Edisi I, Juni 2020

\title{
PENGARUH TERAPI FOOT MESSAGE TERHADAP \\ KECEMASAN PASIEN GAGAL GINJAL KRONIK \\ YANG MENJALANI HEMODIALISA DI RSUD ULIN BANJARMASIN
}

\author{
Amaludin, Mimi' ${ }^{1}$, Hamzah $^{2}$, Muhsinin $^{3}$ \\ ${ }^{1}$ Mahasiswa Pascasarjana Ilmu Keperawatan Universitas Muhammadiyah Banjarmasin, 70114, \\ Indonesia \\ ${ }^{2}$ Staff Dosen Universitas Airlangga Surabaya, 60132,Indonesia \\ ${ }^{3}$ Staff Dosen Pascasarjana Ilmu Keperawatan Universitas Muhammadyah Banjarmasi, 70114, \\ Indonesia
}

Email: mimiamaludin@yahoo.com

\begin{abstract}
Abstrak
Latar Belakang: Kecemasan merupakan masalah psikososial yang dapat berdampak buruk terhadap prognosis penyakit pasien Tujuan penelitian ini mengidentifikasi pengaruh terapi foot massage terhadap kecemasan pada pasien gagal ginjal kronis yang menjalani hemodialisa di Rumah Sakit Ulin Banjarmasin

Metode: Penelitian ini menggunakan desain quasi experiment dengan metode pre-posttest with control group design. Sampel dipilih secara puposive sampling yang berpedoman kepada kriteria penelitian,

Hasil: Sebanyak 40 responden telah dipilih dalam penelitian ini untuk mengikuti terapi foot message dengan karakteristik usia 46-55 tahun (72,5\%), jenis kelamin laki-laki (60\%), tingkat pendidikan SMA 67,5\%), mayoritas responden sudah bekerja (80\%) dengan lama menjalani hemodialisis $<1$ tahun $(67,5 \%)$. Responden yang telah diberikan terapi foot massage menunjukan penurunan skor kecemasan secara signifikan dengan nilai p 0,000. Perbedaan yang bermakna juga ditemukan antara kelompok yang diberikan terapi foot message dengan kelompok kontrol dengan nilai p 0,014.

Kesimpulan: Kecemasan pada pasien gagal ginjal kronis yang menjalani hemodialisa merupakan masalah yang harus segera diatasi. Pemberian terapi foot massage merupakan langkah awal dalam upaya mengurangi kecemasan pada pasien yang menjalani hemodialisis.
\end{abstract}

Kata Kunci: Foot Massage, Gagal Ginjal Kronis, Hemodialis, Kecemasan 


\section{PENDAHULUAN}

Ginjal memainkan peran utama dalam mempertahankan homeostasis dengan mengatur konsentrasi banyak konstituen plasma, terutama elektrolit dan air, dan menghilangkan semua limbah metabolisme (Sherwood, 2016). Pada kondisi gagal ginjal kronis (GGK) ginjal dapat mengalami kehilangan peran dan fungsinya secara progresif dan irreversibel.

Studi Global Buurden of Desease lebih dari 2 juta penduduk dunia mendapatkan perawatan dengan dialysis (WHO, 2018). Di Indonesia kejadian gagal ginjal kronis juga cukup tinggi, populasi penderita gagal ginjal kronis pada umur $\geq 15$ tahun terdiagnosis sebesar 713.783 orang dan yang menjalani HD sebesar 78.281 sedangkan di Kalimantan Selatan sebesar 11.068, angka ini terus meningkat seiring dengan bertambahnya umur (Riset Kesehatan Dasar, 2018).

Penatalaksanaan gagal ginjal pada umumnya lebih bersifat suportif atau mengarah pada upaya mempertahankan fungsi ginjal dan homeostasis, namun apabila sudah mengarah pada GGK dan End Stage Renal Disease (ESRD) lanjut atau apabila laju filtrasi glomerulus $<15 \mathrm{ml} /$ menit, maka pada kondisi ini pasien GGK memerlukan perawatan terapi pengganti ginjal, dialisis dan hemodialisis untuk mengatasi masalah penumpukan zat urea dalam darah (Lewis, et al., 2013).

Upaya yang dilakukan pasien GGK dengan terapi hemodialisa ternyata masih menyisakan masalah yang cukup serius bagi pasien GGK terutama pada aspek psikologis. Hal ini terbukti dari beberapa hasil penelitian yang berhasil mengidentifikasi tingkat kecemasan pasien yang menjalani terapi hemodialisa. Penelitian yang dilakukan oleh Kamil, Agustina, Wahid (2018) menjelaskan bahwa pasien yang menjalani hemodialisa 100\% (183 responden) mengalami kecemasan. Penelitian serupa juga dilakukan oleh Jangkup, Elim, Kandou (2015) yang menunjukkan bahwa pasien penyakit GGK yang menjalani hemodialisa $<6$ bulan memiliki tingkat kecemasan yang signifikan berat dibandingkan dengan yang menjalani hemodialisis $>6$ bulan.

Munculnya keadaan cemas pada pasien GGK yang menjalani terapi hemodialisa dapat terjadi karena kesalahan dalam menanggapi kondisi kesehatannya. Berman (2016) menyatakan bahwa ketika seseorang dalam kondisi sakit, mereka berperilaku dengan cara tertentu yang disebut sosiolog sebagai perilaku penyakit. Perilaku penyakit merupakan suatu mekanisme koping, melibatkan cara individu dalam menggambarkan, memantau, dan menafsirkan gejala-gejalanya, mengambil tindakan perbaikan, dan menggunakan sistem perawatan kesehatan. Kondisi kesehatan yang buruk pada pasien GGK ini menjadi sebuah stressor bagi dirinya yang kemudian ditanggapi dengan cara sebagian adaftif dan sebagian maladaftif. Apabila respon maladaftif ini tidak ditangani dengan baik maka dapat menimbulkan masalah psikososial seperti kecemasan. 
Kecemasan ditandai dengan perasaanperasaan yang mengganggu, gelisah dan ketakutan (Stuart, 2013). Selain itu efek kecemasan juga meningkatkan sekresi kortisol ke dalam darah. Peningkatan sekresi kortisol saat terjadi kecemasan memberikan efek pada tubuh yaitu metabolisme meningkat, tekanan darah meningkat dan terjadi peningkatan asam lemak darah akibat proses lipolysis untuk menyediakan bahan baku bagi gluconeogenesis dan degradasi atau pembongkaran protein untuk menyediakan asam amino yang akan dikerahkan dalam berbagai jalur oksidatif sebagai respon stress (Sherwood, 2016). Keluhan medis umum yang terjadi pada pasien GGK mungkin merupakan manifestasi dari gangguan kecemasan seperti gelisah, GI butterfly, sulit tidur, hipersensitif terhadap kebisingan, ketegangan otot dan masih banyak lagi lainnya (Videbeck, 2011).

Kemampuan pasien GGK dalam menghadapi sumber stress tidak lepas dari peran aktif seorang perawat, selain harus mampu menilai masalah psikologis pasien yang muncul akibat perubahan status kesehatan, perawat juga dituntut untuk mampu memberikan rasa nyaman pada pasien selama menjalani terapi pengobatan dan meminimalisir dampak psikologis yang dapat memperburuk kondisi pasien. Salah satu intervensi yang dilakukan untuk meminimalisir dampak psikologis yaitu terapi foot massage.

Terapi pijat kaki atau foot massage merupakan salah satu terapi alternatif yang dapat memberikan rasa nyaman dan sangat berpotensi mengurangi kecemasan. Terapi ini dipercaya membantu untuk menurunkan tingkat kecemasan dan ditujukan untuk mencapai atau meningkatkan kesehatan. Pada aspek mental, pijatan menyebabkan keadaan rileks, mengurangi tekanan mental, dan meningkatkan kapasitas untuk berpikir jernih. Pada aspek emosional,Sebuah teori menunjukkan bahwa pijatan mendorong system saraf parasimpatis dan cabang sistem otonom yang mengatur tidakan relaksasi, (Fontaine, 2011 dalam Berman, 2016)

Bukti bahwa foot massage dapat membantu mengurangi kecemasan dapat dilihat dari beberapa hasil penelitian eksperimen foot massage yang memberikan dampak positif terhadap kecemasan secara langsung. Penelitian yang dimaksud diantaranya yaitu penelitian yang dilakukan oleh Eguchi, et al. (2016) yang menunjukan bahwa terapi foot message dapat menurunkan skor kecemasan pada laki-laki dan perempuan serta menurunkan tekanan darah sistolik dan diastolik.

Beberapa bukti empiris yang telah dicantumkan diatas tentang foot massage memberikan gambaran bahwa terapi ini mampu memberikan efek positif terhadap penurunan tingkat kecemasan pasien. Meskipun penelitian tersebut belum diuji cobakan pada pasien hemodialisa, akan tetapi dampak yang ditimbulkan dari terapi ini mampu memanipulasi sistem tubuh, menyebabkan kondisi rileks, menyeimbangkan 
aliran energi ke seluruh tubuh dan mengurangi kecemasan. Meskipun demikian, komponen terapi foot massage yang akan diberikan pada pasien GGK masih memerlukan penyesuaian pada level tekanan pijatan dan komponen lainnya agar tidak menimbulkan kerugian seperti menghindari dampak sirkulasi umum. Fokus terapi foot massage yang diberikan lebih diarahkan untuk mencapai tujuan terapeutik tertentu agar tetap dapat memberikan dampak positif terhadap kecemasan.

Kunjungan pasien GGK yang menjalani terapi hemodialisa dapat menjadi salah satu bukti pentingnya terapi hemodialisa bagi penderita GGK. Berdasarkan data yang diperoleh dari rekam medik RSUD Ulin Banjarmasin tercatat bahwa pada tahun 2016 jumlah pasien GGK yang menjalani program Hemodialisa (HD) sebanyak 1499 orang, pada tahun 2017 meningkat menjadi 2898 jiwa, dan pada tahun 2018 kembali meningkat sebanyak 3364 orang.

Studi pendahuluan yang dilakukan pada 15 orang pasien GGK yang menjalani hemodialisa diperoleh data bahwa berdasarkan pengukuran tingkat kecemasan dengan menggunakan instrument H-ARS pada 15 orang pasien GGK yang menjalani HD 12 $(80 \%)$ orang diantaranya masuk dalam kategori kecemasan ringan, sedangkan 3 (20\%) orang lainnya masuk dalam kategori kecemasan sedang.

Kecemasan pada pasien GGK yang menjalani HD dapat berpotensi meningkatkan rasa sakit, prognosis yang buruk, pengobatan tertunda serta meningkatkan resiko mordibitas dan mortalitas apabila tidak ditangani dengan serius. Bahkan apabila kecemasan sudah sampai pada tingkatan panik maka respon psikologis yang dapat muncul adalah kemungkinan delusi dan halusinasi yang berujung pada upaya bunuh diri (Videback, 2011). Melihat besarnya pengaruh kecemasan terhadap keberhasilan program pengobatan pasien GGK yang menjalani terapi HD, maka penatalaksanaan yang diberikan pada pasien tersebut tidak cukup hanya difokuskan pada aspek fisik saja (hemodialisa), akan tetapi ada faktor lain yang juga harus direspon oleh seorang perawat. Watson sebagai salah seorang teoris keperawatan pernah menyampaikan teori caring yang terkenal dengan konsep utamanya "10 faktor karatif" yang didalamnya memuat faktor kratif ke 8 dimana dijelaskan bentuk kepedulian perawat dengan menciptakan lingkungan penyembuhan di semua tingkatan (lingkungan fisik dan nonfisik, energi dan kesadaran yang halus, di mana keutuhan, keindahan, kenyamanan, martabat, dan kedamaian ditingkatkan) (Alligood, 2014).

Bentuk kepedulian yang dimaksud pada teori Watson adalah segala upaya untuk menyediakan lingkungan mental, fisik, dan sosial yang mendukung, serta melindungi. Proses menciptakan lingkungan penyembuhan di semua tingkatan (lingkungan fisik dan energi yang halus serta nonfisik, energi dan kesadaran yang halus, dimana keutuhan, 
keindahan, kenyamanan, martabat, dan kedamaian diperkuat) dimungkinkan dapat terealisasi melalui terapi foot massage. Sehingga dengan adanya upaya mengintegrasikan foot massage yang telah disesuaikan untuk pasien GGK di dalam program terapi hemodialisa diharapkan dapat menjadi sebuah stimulus yang bermakna dan dapat memberikan efek positif bagi pasien dalam mengurangi kecemasan dan sebagai bentuk kepedulian perawat terhadap pemenuhan kebutuhan dasar manusia (kebutuhan rasa nyaman) selama menjalani program pengobatan.

Tujuan penelitian ini adalah untuk mengidentifikasi pengaruh terapi foot massage terhadap kecemasan pada pasien gagal ginjal kronis yang menjalani hemodialisa di Rumah Sakit Ulin Banjarmasin.

\section{METODE PENELITIAN}

Metode penelitian yang digunakan dalam penelitian ini adalah quasy experiment dengan desain penelitian one group pre test and post test with control group. Penelitian ini dilakukan di RSUD Ulin Banjarmasin di ruang hemodialisa kepada 40 responden yang dipilih secara purposive sampling yang berpedoman pada kriteria inklusi yaitu; usia responden $>18$ tahun, tidak mengalami gangguan saraf pada kaki, tidak mengalami pembengkakan pada ekstremitas bawah, tidak mempunyai alergi terhadap minyak yang digunakan dan telah menjalani hemodialisa $>6$ bulan.
Sampel yang telah dipilih sesuai kriteria kemudian diberikan penjelasan mengenai terapi diberikan. Sebelum terapi diberikan, responden diukur tingkat kecemasan menggunakan kuesioner Hamilton Anxiety Rating Scale (HARS). Responden dengan gejala kecemasan ringan dan sedang dapat mengikuti kegiatan terapi, namun bila ditemukan kecemasan berat responden akan dirujuk ke kesehatan mental. Pada proses pengambilan data peneliti akan melakukan teknik ketersamaran (masking, blinding) untuk menghindari bias baik yang berasal dari peneliti, peserta, atau evaluator. Jenis ketersamaran yang digunakan adalah tersamar tunggal (single mask), dimana peneliti melibatkan seorang asisten dengan kualifikasi pendidikan Diploma III Fisioterapi yang telah melalui proses apersepsi dengan peneliti. Asisten penelitian juga bertugas memberikan intervensi foot massage pada kelompok intervensi. Terapi foot massage dimulai 20 menit sebelum pelaksanaan HD dengan durasi pelaksanaan \pm 10 menit. Dua hari setelah pemberian terapi foot massage pasien kembali diukur tingkat kecemasan. skor yang diperoleh kemudian di analisis menggunakan uji statistik independent sample t test.

\section{HASIL PENELITIAN}

Karakteristik responden berdasarkan umur, jenis kelamin, pendidikan, pekerjaan dan lama menjalani hemodialisa di RSUD Ulin Banjarmasin dapat dilihat pada tabel 1. 
Jurnal Keperawatan Suaka Insan| Volume 5 Edisi I, Juni 2020

Tabel 1. Karakteristik Umur, Jenis Kelamin, Pendidikan, Pekerjaan dan Lama Menjalani Hemodialisa di Rumah Sakit Ulin Banjarmasin $(\mathrm{n}=40)$

\begin{tabular}{cclc}
\hline Variabel & Kategori & \multicolumn{1}{c}{$\Sigma$} & \multicolumn{1}{c}{$\%$} \\
\hline & Dewasa & 7 & 17,5 \\
& Akhir & 29 & 72,5 \\
Usia & Lansia & 4 & 10,0 \\
& Awal & & \\
& Lansia & & \\
& Akhir & & \\
\hline Jenis & Laki-laki & 24 & 60,0 \\
Kelamin & Perempuan & 16 & 40,0 \\
\hline Pendidikan & Rendah & 9 & 22,5 \\
& Sedang & 27 & 67,5 \\
& Tinggi & 4 & 10.0 \\
\hline Pekerjaan & Tidak & 8 & 20,0 \\
& Bekerja & 32 & 80,0 \\
& Bekerja & & \\
\hline Lama HD & $<1$ tahun & 27 & 67,5 \\
& $\geq 1$ tahun & 13 & 32,5 \\
\hline
\end{tabular}

Tabel 1. menunjukan bahwa mayoritas responden kategori umur masa lansia awal (46-55 tahun) 72,5\%, jenis kelamin laki-laki lebih banyak dari jenis kelamin perempuan yaitu 60,0\%. Bila dilihat dari tingkat pendidikan responden dalam penelitian ini menunjukan bahwa mayoritas responden memiliki tingkat pendidikan sedang (SMA) 67,5\%. Sedangkan pada krakteristik pekerjaan responden menunjukan bahwa mayoritas responden memiliki pekerjaan sebesar $80 \%$. Hasil penelitian juga menunjukan bahwa paling banyak responden menjalani hemodialisis dalam periode kurang dari satu tahun yaitu $67,5 \%$.

Gambaran skor kecemasan sebelum dan setelah terapi foot massage serta skor kecemasan sebelum dan sesudah intervensi foot massage pada kelompok kontrol dijelaskan pada tabel 2.

Tabel 2. Gambaran Skor Kecemasan pada Kelompok Intervensi dan Kelompok Kontrol pada Responden yang Menjalani Hemodialisa di Rumah Sakit Ulin Banjarmasin $(n=40)$

\begin{tabular}{lccc}
\hline \multicolumn{1}{c}{ Variabel } & Mean & Min-Maks & 95\% CI \\
\hline $\begin{array}{l}\text { Skor kecemasan sebelum } \\
\text { terapi foot massage }\end{array}$ & 20,70 & $15-27$ & $19,23-22-17$ \\
\hline $\begin{array}{l}\text { Skor kecemasan setelah } \\
\text { terapi foot massage }\end{array}$ & 18,15 & $13-25$ & $16,81-19,49$ \\
\hline $\begin{array}{l}\text { Skor kecemsaan sebelum } \\
\text { terapi foot massage pada } \\
\text { kelompok kontrol }\end{array}$ & 20,90 & $14-27$ & $19,14-22,66$ \\
\hline $\begin{array}{l}\text { Skor kecemasan setelah } \\
\text { terapi foot massage pada } \\
\text { kelompok kontrol }\end{array}$ & 20,90 & $14-27$ & $19,12-22,68$ \\
\hline
\end{tabular}

Tabel 2. menujukkan bahwa rata-rata skor kecemasan responden yang menjalani hemodialisa di RSUD Ulin Banjarmasin sebelum diberikan terapi foot massage adalah 20,70 dan setelah diberikan intervensi foot massage terjadi penurunan skor kecemasan yaitu 18,15. Pada kelompok kontrol rata-rata skor kecemasan responden yang menjalani hemodialisa di RSUD Ulin Banjarmasin sebelum diberikan terapi foot massage pada kelompok intervensi yaitu 20,90 dan setelahnya tidak menunjukan perubahan dengan skor rata-rata yaitu 20,90.

Pengaruh faktor internal dan faktor eksternal yang terkait sosial demografi terhadap kecemasan dijelaskan pada tabel 3.

Tabel 3. Pengaruh Umur, Jenis Kelamin, Tingkat Pendidikan, Pekerjaan dan Lama Menjalani Terhadap Kecemasan Pasien Gagal Ginjal Kronis yang Menjalani Hemodialisa di RSUD Ulin Banjarmasin. 
Jurnal Keperawatan Suaka Insan| Volume 5 Edisi I, Juni 2020

\begin{tabular}{llll}
\hline \multicolumn{1}{c}{ Variabel } & n & Rerata & Nilai P \\
\hline Umur & & & \\
Dewasa Akhir & 7 & 18,71 & $0,636^{\mathrm{a}}$ \\
Lansia Awal & 29 & 19,59 & \\
Lansia Akhir & 4 & 20,50 & \\
\hline Jenis Kelamin & & & \\
$\quad$ Laki-laki & 24 & 19,04 & $0,262^{\mathrm{b}}$ \\
$\quad$ Perempuan & 16 & 20,25 & \\
\hline $\begin{array}{l}\text { Pendidikan } \\
\text { Rendah }\end{array}$ & 9 & 19,76 & $0,948^{\mathrm{a}}$ \\
$\quad$ Sedang & 27 & 19,41 & \\
$\quad$ Tinggi & 4 & 20.00 & \\
\hline $\begin{array}{l}\text { Pekerjaan } \\
\text { Tidak Bekerja }\end{array}$ & 8 & 19,88 & $0,763^{\mathrm{b}}$ \\
Bekerja & 32 & 19,44 & \\
\hline Lama HD & & & \\
$\quad<1$ tahun & 27 & 21,00 & $0,000^{\mathrm{b}}$ \\
$\quad 1$ tahun & 13 & 16,46 & \\
\hline a $=$ one way anova, ${ }^{\mathrm{b}}=$ independent sampel test
\end{tabular}

Tabel 3. menunjukan bahwa tidak ada pengaruh umur $(\mathrm{p}=0,636)$, jenis kelamin $(\mathrm{p}=0,262)$, tingkat pendidikan $(\mathrm{p}=0,984)$ dan pekerjaan $(0,763)$ terhadap kecemasan pasien gagal ginjal kronis yang menjalani hemodialisa di RSUD Ulin Banjarmasin. Hasil analisis lama menjalani hemodialisa terhadap kecemasan menjelaskan ada pengaruh signifikan dengan nilai $\mathrm{p}=0,000$.

Hasil analisis perbedaan rata-rata skor kecemasan sebelum dan setelah pemberian terapi foot massage dijelaskan pada tabel 4.

Tabel 4. Perbedaan Rata-Rata Skor Kecemasan Sebelum dan Setelah Pemberian Terapi Foot Massage pada Kelompok Intervensi.

\begin{tabular}{llccc}
\hline \multicolumn{1}{c}{ Variabel } & n & Rerata & P \\
\hline $\begin{array}{l}\text { Sebelum intervensi foot } \\
\text { massage }\end{array}$ & 20 & 20,70 & 0,000 \\
$\begin{array}{l}\text { Setelah intervensi foot } \\
\text { massage }\end{array}$ & & 18,15 & \\
\hline
\end{tabular}

Tabel 4. menunjukan bahwa terdapat perbedaan yang rata-rata skor ansietas sebelum dan setelah pemberian terapi foot massage dengan nilai p 0,000. Hasil ini menunjukan bahwa ada perbedaan yang signifikan sebelum dan setelah diberikan terapi foot massage pada pasien gagal ginjal kronis yang menjalani hemodialisis.

Tabel 5. Hasil Analisis Pengaruh Terapi Foot Massagee Terhadap Kecemasan Pasien Gagal Ginjal Kronis yang Menjalani Hemodialisa di RSUD Ulin Banjarmasin.

\begin{tabular}{lcccc}
\hline \multicolumn{1}{c}{ Variabel } & n & Rerata & Nilai P \\
\hline $\begin{array}{l}\text { Kelompok terapi foot } \\
\begin{array}{l}\text { message } \\
\text { Kelompok control }\end{array}\end{array}$ & 20 & 18,15 & 0,014 \\
\hline
\end{tabular}

Tabel 5. menunjukan bahwa terdapat perbedaan yang rata-rata skor ansietas antara kelompok yang diberikan terapi foot massage dan kelompok kontrol dengan nilai p 0,014. Hasil ini menunjukan bahwa ada perbedaan yang signifikan antara kelompok yang diberikan terapi foot massage dengan kelompok kontrol terhadap kecemasan pada pasien gagal ginjal kronis yang menjalani hemodialisis.

\section{PEMBAHASAN}

Hasil temuan penelitian menunjukan mayoritas responden berumur antara 46-55 tahun. Temuan ini sejalan dengan kasus gagal ginjal kronik yang menjalani hemodialisa di Indonesia. Berdasarkan usia, pasien gagal ginjal kronik yang menjalani hemodialisis terbanyak adalah kelompok usia 45-64 tahun, baik pasien baru maupun pasien aktif (Depkes, 2018). Hasil penelitian ini sejelan dengan penelitian oleh Gerogianni, et al. (2017) yang 


\section{Jurnal Keperawatan Suaka Insan| Volume 5 Edisi I, Juni 2020}

menunjukan responden dengan penyakit ginjal kronis yang menjalani hemodialisa memiliki usia yang berentang antara 54-72 tahun. Hasil yang sama juga dijelaskan dalam penelitian Alqarni, et al. (2019) bahwa rata-rata umur responden yang mengalami penyakit ginjal kronis dan menjalani hemodialisis adalah 52, 33 tahun. Menurut Denic, et al. (2016) pada usia yang leih tua terjadi perubahan struktural mikro-anatomi ginjal termasuk penurunan jumlah glomerulus secara fungsional. Setiap dekade pertambahan umur fungsi ginjal menurun $10 \mathrm{ml} /$ menit/ $1,73 \mathrm{~m}^{2}$. Usia dekade keempat terjadi kerusakan ringan dengan nilai GFR $60-89 \mathrm{ml} / \mathrm{menit} / 1,73 \mathrm{~m}^{2}$. Penurunan tersebut adalah sama dengan 10 persen dari kemampuan normal fungsi ginjal. Pada lansia terjadi penurunan secara fungsional ginjal dalam hal filtrasi glomerulus dan beresiko mengembangkan penyakit ginjal kronis dan mereka juga berisiko lebih tinggi untuk penyakit ginjal akut.

Hasil analisis perbandingan skor kecemasan antar kelompok umur menunjukan tidak ada hubungan yang signifikan. Hasil penelitian tersebut sejalan dengan penelitian sebelumnya oleh Juan Ng, et al (2014) bahwa usia tidak mempengaruhi kecemasan pasien gagal ginjal kronis yang menjalani hemodialisis di pelayanan kesehatan. Hasil penelitian ini juga diperkuat oleh penelitian Kumar, Khandelia \& Garg (2018) bahwa umur tidak mempengaruhi kecemasan pasien yang menjalani hemodialisis.
Tidak adanya hubungan usia dengan kecemasan disebabkan oleh tidak adanya parameter klinis yang membuktikan faktor sosiodemografi mempengaruhi respon emosional seseorang terhadap penyakit yang dialami (Juan Ng, et al, 2014). Kecemasan yang dialami tetap tidak berbeda dari waktu ke waktu dengan sebagian besar pasien melaporkan gejala kecemasan atau depresi. Pasien yang menjalani gagal ginjal kronik yang menjalani hemodialisis memerlukan perawatan dalam waktu yang lama. Perawatan ini tidak menyembuhkan seseorang dari penyakit ginjal yang dialami. Proses perawatan dengan menjalani hemodialisis telah mengubah gaya hidup pasien dan keluarga seperti rasa kehilangan terhadap integritas sistem tubuh (Farrell, 2017).

Hasil penelitian ini menunjukan bahwa jenis kelamin laki-laki lebih banyak bila dibandingkan jenis kelamin perempuan. Hal ini sejalan dengan survey yang dilakukan oleh Depkes tahun 2018 yang menunjukan bahwa prevalensi gagal ginjal di Indonesia lebih dominan pada laki-laki $(0,3 \%)$, lebih tinggi dibandingkan dengan perempuan $(0,2 \%)$ yang menjalani hemodialisa. hasil penelitian ini sejalan dengan penelitian Gerogianni, et al (2017) juga menujukan mayoritas responden yang menjalani hemodialisis adalah laki-laki $63,3 \%$. Hasil penelitian juga didukung oleh penelitian Khan et al. (2019) yang menunjukan bahwa jenis kelamin laki-laki paling banyak mengalami penyakit ginjal kronis yang menjalani hemodialisis $(55,5 \%)$. 
Perkembangan penyakit ginjal kronik mungkin berbeda tergantung pada jenis kelamin. Pasien pria menunjukkan prevalensi penyakit ginjal kronis yang jauh lebih tinggi dan tingkat kejadian daripada yang diamati pada pasien wanita (Chang, et al, 2016). Survei yang dilakukan oleh Iseki (2008) untuk terapi dialisis menunjukkan perbedaan jenis kelamin dan usia rata-rata pada awal dialisis. Hasil survey tersebut menunjukan bawah jenis kelamin laki-laki lebih banyak menderita penyakit ginjal kronis. Perjalanan alami perkembangan penyakit ginjal kronis sebagian besar tidak diketahui. Faktor risiko konvensional terjadinya aterosklerosis seperti hipertensi, diabetes mellitus, hiperlipidemia, dan riwayat penyakit serebrovaskuler turut mengembangkan resiko penyakit ginjal kronis. Selain itu temuan Abbate, et al. (2012) pria dengan diabetes memiliki risiko nefropati yang lebih tinggi daripada wanita dengan diabetes.

Hasil penelitian ini juga menunjukan bahwa skor rata-rata kecemasan pada perempuan lebih besar dari skor kecemasan pada laki-laki. Namun, secara statistik tidak ditemukan perbedaan yang signifikan antara jenis kelamin laki-laki dan perempuan. Hasil ini sejalan dengan penelitian oleh Brito, et al (2019), jenis kelamin tidak mempengaruhi kecemasan pada pasien yang menjalani dialisis. Hal yang sama juga dijelakan oleh Juan Ng et al (2014) bahwa jenis kelamin tidak mempengarui kecemasan pada pasien gagal ginjal kronis yang menjalani hemodialisis. Temuan lain yang mendukuang hasil penelitian ini juga dijelaskan oleh Khan, et al (2019) bahwa jenis kelamin tidak mempengaruhi depresi pada responden yang mengalami penyakit ginjal kronis yang menjalani hemodialisa.

Beberapa penelitian terdahulu menunjukan bahwa ada perbedaan hasil dengan penelitian ini. Menurut Kinrys \& Wygant (2005), perempuan memiliki risiko yang jauh lebih tinggi terkena gangguan kecemasan seumur hidup dibandingkan dengan pria.

Tidak ada perbedaan yang signifikan antara jenis kelamin terhadap kecemasan dapat disebabkan oleh stresor yang dialami oleh individu tersebut. Perjalanan penyakit ginjal kronis dan perawatan hemodialisis mengubah gaya hidup pasien. Jumlah waktu yang diperlukan untuk cuci darah dan kunjungan dokter dan sakit kronis dapat menciptakan konflik, frustrasi, rasa bersalah dan depresi. Hal ini dapat mengarah kepada keputusasaan, dan upaya bunuh diri (Ferrel, 2017).

Hasil penelitian menunjukan bahwa sebagian besar responden dalam penelitian ini memiliki tingkat pendidikan sedang (SMA) $67,5 \%$. Hasil penelitian ini sejelan dengan penelitian sebelumnya oleh Kuniawati \& Asikin (2018) bahwa jumlah responden paling banyak yang menjalani hemodialisis di Rumkital Dr. Ramelan Surabaya adalah tingkat SMA (49,1\%). Pada penelitian lainnya oleh Polkandrioti, et al (2017) juga menunjukan bahwa tingkat pendidikan sekolah 


\section{Jurnal Keperawatan Suaka Insan| Volume 5 Edisi I, Juni 2020}

dasar dan SMA mendominasi jumlah kunjungan pasien yang menjalani hemodialisis yaitu 71,9\%. Menurut Wilson \& McLemore (1997) peran pendidikan sangat penting dalam berbagai aspek kesehatan telah dievaluasi dan peran manfaatnya dalam berbagai hasil kesehatan. Hal ini juga dijelaskan oleh Goldfarb-Rumyantzev, et al. (2006) tingkat pendidikan yang lebih tinggi juga telah terbukti berhubungan dengan kelangsungan hidup cangkok yang lebih baik pada pasien transplantasi ginjal. Penelitian oleh Khattak, et al (2012) bahwa pendidikan perguruan tinggi dikaitkan dengan kelangsungan hidup yang lebih tinggi pada pasien dialisis dibandingkan dengan mereka yang tidak pernah menyelesaikan sekolah menengah.

Pada penelitian ini tidak ada perbedaan yang signifkan antara tingkat pendidikan terhadap kecemasan pasien gagal ginjal kronis yang menjalani hemodialisa. Hasil penelitian ini sejalan dengan penelitian oleh Cantekin, et al (2014) bahwa tingkat pendidikan seseorang tidak memiliki hubungan terhadap kecemasan pasien gagal ginjal kronis yang menjalani hemodialisis. Penelitian ini juga diperkuat oleh Kumar, Khandelia \& Garg (2018) bahwa pendidikan tidak mempengaruhi kecemasan pasien yang menjalani hemodialisis.

Kecemasan yang terjadi dapat dialami oleh setiap orang walaupun tingkat pendidikan seseorang berbeda. Kecemasan yang dialami dapat terjadi merupakan kombinasi dari berbagai faktor seperti faktor biologis, faktor psikologis dan pengalaman hidup yang menantang seperti peristiwa kehidupan yang penuh tekanan atau traumatis. Gejala panik maupun kecemasan umum dapat terjadi akibat kondisi medis, seperti penyakit jantung, paruparu, ataupun pada organ lainnya (Rector, at al. 2008).

Tinggi rendahnya status pendidikan seseorang tidak dapat mempengaruhi persepsi yang dapat menimbulkan kecemasan. Kecemasan yang terjadi pada pasien penyakit ginjal kronis dapat dipengaruhi oleh kondisi adanya penyakit serius yang mengancam jiwa.

Hasil penelitian ini menjelaskan bahwa tidak ada pengaruh pekerjaan terhadap kecemasan pasien gagal ginjal kronik yang menjalani hemodialisis. Hasil penelitian ini sejalan dengan penelitian sebelumnya oleh Cantekin, Curcani, Tan (2014) bahwa pekerjaan tidak mempengaruhi tingkat kecemasan pasien gagal ginjal kronis yang menjlani hemodialisis. Hasil penelitian yang sama juga dikemukakan oleh Alqarni, et al (2019) bahwa pekerjaan seseorang tidak mempengaruhi kejadian cemas pada pasien gagal ginjal kronis yang menjalani hemodialisis. Kemudian juga di jelaskan oleh Juan Ng, et al (2014) bahwa pekerjaan tidak memiliki hubungan terhadap kecemasan pasien gagal ginjal kronis yang menjalani hemodialisis.

Hasil penelitian ini juga menjelaskan bahwa $80 \%$ responden masih bekerja. Seseorang yang memiliki pekerjaan memperoleh pengasilan yang tetap. Penghasilan yang diperoleh dapat 
dimanfaatkan untuk melakukan perawatan selama menjalani hemodialisis. Hasil penelitian ini sejalan dengan penelitian oleh Polikandrioti, et al. (2017) bahwa sebagian besar responden yang menjalani hemodialisis masih memiliki pekerjaan dan berpenghasilan sebagai pensiun yaitu $76,3 \%$. Pekerjaan berikaitan dengan pengahasilan seseorang yang dapat mempengaruhi status kesehatan. Semakin tinggi pengahasilan seseorang semakin baik upaya memperoleh perawatan kesehatan, sebaliknya jika tidak memperoleh penghasilan semakin sulit upaya seseorang mempertahankan status kesehatan.

Kecemasan yang terjadi pada pasien gagal ginjal kronis yang menjalani hemodialisis dapat disebabkan sulitnya beradaptasi dengan kondisinya saat ini. Pasien dengan gagal ginjal kronis diharuskan untuk menerima diagnosis yang mengancam jiwa dan kebutuhan untuk perawatan seumur hidup, mempelajari teknik dialisis, mengintegrasikan pengobatan ke dalam hidup mereka, dan mengatasi transisi / kegagalan pengobatan, efek samping, dan komplikasi (Cukor, et al. 2007).

Pekerjaan dikaitkan dengan kemampuan seseorang untuk memenuhi kebutuhan terutama perawatan kesehatan. Pasien yang menjalani hemodialisis sering kali kelihangan pekerjaan mereka, namun pekerjaan bukanlah stresor utama pada terhadap gangguan kecemasan pada pasien gagal ginjal kronis. Penyebab kecemasan yang dirasakan oleh pasien adalah ancaman terhadap perubahan status kesehatan dan prosedur dialisis (Goyal, et al. 2018).

Hasil penelitian menunjukan $67,5 \%$ pasien menjalani hemodialisis $<1$ tahun. Hasil penelitian juga menunjukan ada pengaruh lama menjalani hemodialisis terhadap kecemasan pasien gagal ginjal kronis yang menjalani hemodialis. Namun, secara klinis tidak ada perbedaan kecemasan antara durasi menjalani hemodialisis $<1$ tahun dan durasi lebih dari 1 tahun.

Penyebab dari kecemasan yang dialami oleh pasien ada awal menjalani terapi hemodialisis adalah syok didiagnosis dengan penyakit ginjal kronis dan rasa sakit awal dari prosedur dialisis. Pasien dengan dialisis lebih rentan terhadap penyakit kejiwaan karena memiliki perjalanan kronis yang melemahkan dengan hasil yang buruk yang mengarah ke perubahan gaya hidup utama dengan gangguan pekerjaan dan konsekuensi keuangan yang diakibatkannya. Pasien yang menjalani hemodialisis mengahadapi tekanan yang berat dimana dalam semua aspek rutinitas seharihari terganggu (Goyal, et al. 2018).

Penelitian ini juga didukung oleh beberpa penelitian sebelumnya. Penelitian oleh Alfikrie et al., (2019) bahwa ada hubungan antara lama menjalani hemodialisis dengan kecemasan pasien. Hasil penelitiannya juga menunjukan sebagian besar pasien menjalani hemodialisis kurang dari satu tahun. Hal yan sama juga dijelaskan oleh Jangkup, dkk. (2015) yang menunjukkan bahwa pasien penyakit GGK yang menjalani hemodialisa $<6$ 
Jurnal Keperawatan Suaka Insan| Volume 5 Edisi I, Juni 2020

bulan memiliki tingkat kecemasan yang signifikan berat dibandingkan dengan yang menjalani hemodialisis >6 bulan. Hasil penelitian yang sama juga dikemukakan oleh Gerogianni, et al (2017) menunjukan bahwa terdapat hubungan antara lama menjalani hemodialisis dengan kecemasan pasien.

Pada tahap awal pasien yang menjalani terapi dialisis terjadi perubahan dalam gaya hidup. Seorang pasien mungkin hanya dibatasi untuk istirahat dan perubahan pola makan, tetapi kemudian ketika penyakitnya berkembang, pasien secara fisik mungkin tidak dapat mengatasi pekerjaannya dan mungkin mengambil cuti medis untuk dirawat di rumah sakit, yang dapat menyebabkan kompromi pekerjaannya dan selanjutnya mempengaruhi kondisi keuangan keluarga (Kumar, et al. 2003).

Pasien yang menjalani hemodialisis harus dapat beradaptasi dengan baik. Menurut Sadock, et al, (2015) pengalaman awal pasien dalam pengobatan merupakan faktor penting yang sangat berharga yang terjadi pada individu. Pengalaman awal ini sebagai bagian penting dan bahkan sangat menentukan bagi kondisi mental individu di kemudian hari.

Kecemasan yang dialami oleh pasien yang menjalani hemodialisis dapat bervariasi sesuai dengan koping yang digunakan. Pasien yang mampu beradaptasi dapat menerima keadaan dan menjalani terapi hemodialisis dengan tenang walaupun sebagain dari pasien masih memiliki kecemasan yang sudah berkurang. Sebaliknya pasien yang belum mampu beradaptasi dengan kondisi yang dialami memerlukan bantuan dari perawat atau terapis untuk mengatasi masalah yang dirasakannya.

Hasil analisis menunjukkan adanya perbedaan yang bermakna antara skor rerata kecemasan pretest dan posttest pada kelompok yang diberikan terapi foot message dengan $p$ value $=0,000$.

Hasil penelitian ini memiliki kesamaan dengan penelitian yang dilakukan oleh Eguchi, et al. (2016) yang menyimpulkan bahwa terapi foot message dapat menurunkan skor kecemasan pada laki-laki dan perempuan di Jepang. Meskipun terdapat perbedaan dari segi karakteristik responden pasien GGK juga masih memungkinkan untuk menerima manfaat positif dari foot massage itu sendiri terutama manfaat terapeutik yang mengarah pada aspek psikologis.

Penelitian Afianti dan Mardhiyah (2017) juga menyimpulkan dampak positif lain dari foot massage terhadap komponen kecemasan yaitu adanya perbedaan yang bermakna rerata skor kualitas tidur setelah diberikan terapi foot massage. Kualitas tidur yang dimaksud tidak selalu berhubungan dengan kuantitas tidur karena masalah kualitas tidur ini dapat muncul pada pasien dengan kecemasan ringan sebagai respon fisiologis (Videbeck, 2011). Pada penelitian ini kualitas tidur juga masuk di dalam komponen penilaian kecemasan Zung Self Rating Anxiety Scale. 


\section{Jurnal Keperawatan Suaka Insan| Volume 5 Edisi I, Juni 2020}

Beberapa bukti empiris tentang foot massage menunjukkan bahwa terapi ini mampu memberikan dampak positif dalam mengurangi kecemasan pasien. Sebagaimana yang disampaikan bab sebelumnya bahwa foot massage merupakan bagian dari komunikasi dalam perawatan yang dapat memberikan dampak terapeutik pada aspek psikologis, hal ini secara otomatis mampu meningkatkan harga diri responden yang juga merupakan faktor yang turut mempengaruhi munculnya kecemasan.

Hasil pengukuran menunjukkan bahwa rerata skor kecemasan kelompok intervensi lebih rendah 2,75 dari pada kelompok kontrol dan analisis terhadap selisih rerata skor tersebut menghasilkan kesimpulan adanya perbedaan bermakna antara rerata skor kecemasan antara kelompok intervensi dan kelompok kontrol dengan $p$ value $=0,014$.

Pemberian stimulasi sensori dalam bentuk foot massage juga pernah diuji cobakan sebelumnya oleh Eguchi, et al. (2016) menyimpulkan bahwa terapi foot message dapat menurunkan skor kecemasan pada lakilaki dan perempuan di Jepang. Meskipun penelitian tersebut tidak dilakukan pada pasien GGK, namun dampak positif yang diterima oleh responden telah membuktikan adanya kontribusi positif foot massage secara umum dalam mengurangi kecemasan.

Perubahan skor kecemasan pada penelitian ini menandakan bahwa pada kondisi tertentu, rasa cemas sangat mungkin dipengaruhi oleh stimulus pijatan yang merupakan bagian dari lingkungan ekstenal. Lindgren (2012) menyatakan bahwa secara fisiologis sentuhan pijatan pertama kali akan diproses oleh sel reseptor yang ada di kulit dan kemudian dilanjutkan dengan pengiriman sinyal neurokimia ke wilayah besar korteks korteks somatosensor yang mengingatkan setiap kontak sentuhan dengan dunia luar. Tahapan ini sangat ditentukan oleh faktor kontekstual yang melibatkan prefrontal cortex (PFC). Bentuk kontekstual yang dimaksud adalah adanya penjelasan mengenai stimulus yang diterima, apakah dinilai sebagai stimulus yang menyenangkan atau stimulus yang menyakitkan. Sinyal yang dianggap menyenangkan akan mengaktifkan orbitofrontal cortex (OFC) lateral dan pregenual anterior cingulated cortex (pgACC). Aktivasi sistem sistem ini memungkinkan seseorang untuk menikmati rangsangan tertentu, memberikan motivasi, dan dengan demikian mengendalikan beberapa perilaku dan respons tubuh seperti pengaktifan hormon serotonin, termasuk di dalamnya perbaikan kapasitas antiansietas dari reseptor GABA.

Terapi foot massage yang dilakukan pada penelitian ini ternyata tidak hanya direspon oleh organ sensori peraba (kulit) saja, namun juga melibatkan beberapa organ sensori lainnya seperti pendengaran dan penglihatan. Penjelasan peneliti mengenai prosedur serta manfaat dari pijatan yang dilakukan dapat menyatukan persepsi dan harapan selama proses pijatan dibanding dengan pijatan yang dilakukan tanpa adanya penjelasan. Hal ini 
sangat mungkin membantu responden meningkatkan rasa penghargaan terhadap dirinya sendiri serta mempengaruhi pengolahan stimulus yang diterima oleh otak. Selama proses pijatan, responden juga dapat mengamati setiap ritme pijatan, bahkan irama yang teratur dan dapat diprediksi oleh klien diyakini memiliki efek sedatif (Walton, 2011). Penjadwalan waktu pijatan sebelum prosedur hemodialisa, juga turut membantu responden untuk mengelola rasa sakit atau kecemasan yang disebabkan oleh prosedur tersebut.

\section{KESIMPULAN}

Hasil penelitian menunjukan tidak ada pengaruh usia, jenis kelamin, pendidikan dan pekerjaan terhadap kecemasan pasien gagal ginjal kronis yang menjalani hemodialisis, namun bila ditinjau dari lama menjalani hemodialisis terhadap kecemasan terdapat pengaruh yang signifikan. Hasil penelitan juga menunjukan ada pebedaan yang bermakna kelompok yang diberikan terapi foot message menunjukan penuruan skor kecemasan lebih rendah 2,75 dari pada kelompok kontrol.

Perawat dapat memberikan terapi foot massage sebelum pelaksanaan hemodialisa. Hal ini dapat memberikan efek relaksasi kepada pasien selama menjalani hemodialisa, mengurangi beban pikiran dan kecemasan yang dialami oleh pasien.

\section{DAFTAR PUSTAKA}

Abbate, R., Mannucci, E., Cioni, G., et al (2012). Diabetes and sex: from pathophysiology to personalized medicine. Intern Emerg Med. 7 (3):S215S219

Afianti \& Mardiah. (2017) Pengaruh Terapi Foot Massage pada Pasien di Ruang ICU.5(1)

Alfikrie, F., Sari, L., Akbar, A. (2019). Factors associated with anxiety in patients with chronic kidney disease undergoing hemodialysis: a crossectional study. International Journal of Nursing, Health and Medicine. 2 (2).

Alligood, M.R. (2014). Nursing Theorists and Their Work (8th Ed). St. Louis : MosbyElseiver.

Alqarni, A.M., Alghamdi, E.A., Alaqil, N.A., Alzahrani, A.H., Aldhfyan, Y.M., Alruwaili, S.A (2019). Prevalence of anxiety and depression and its related influencing factors among patients with end-stage renal disease on hemodialysisi Al-Kharj, Saudi Arabia. International Journal of Medical Research \& Health Sciences. 8 (1). Pp 55-62.

Berman, A., et al. (2016). Kozier \& Erb's Fundamentals of Nursing : Concepts, Process and Pratice. $10^{\text {th }} \mathrm{Ed}$. New Jersey : Pearson Education.

Brito, D.C.S., Machado, E.L., Reis, I.A., Carmo, L.P.F., Cherchiglia, M.L. (2019). Depression and anxiety among patients undergoing dialysis and kidney transplantation: a cross-sectional study. Sou Paulo Medical Journal. 137(2). Pp. 137-147. DOI. 10.1590/15163180.2018.0272280119

Cantekin, I., Curcani, M., Tan, M. (2014). Determining the anxiety and depression levels of pre-dialysis patients in eastern Turkey. Renal Failure. 36(5). 678-681 
Chang, P., Chien, L., Lin, Y., et al. (2016). Risk factors of gender for renal progression in patients with early chronic kidney disease. Medicine. 95(30). 1-7

Denic, A., Glassock, R.J., Rule, A.D. (2016). Structural and functional changes with the aging kidney. Adv Chronic Kidney Dis. 23(1). Pp. 19-28.

Depkes. (2018) . Cegah dan Kendalikan Penyakit Ginjal Dengan Cerdik Dan Patuh. Diakses di https://www.depkes.go.id/article/print/180 30700007/cegah-dan-kendalikanpenyakit-ginjal-dengan-cerdik-danpatuh.html. Diperoleh tanggal 10 Januari $\underline{2019}$

Eguchi, E., Funakubo, N., Tomooka, K., Ohira, T., Ogino, K., Tanigawa, T. (2016). The effects of aroma foot massage on blood pressure and anxiety in Japanese community-dwelling men and women: a crossover randomized controlled trial. Plos One. DOI: 11(3): e0151712. doi:10.1371/journal.pone.0151712

Farrell, M. (2017). Smeltzer \& Bare's Text Book of Medical Surgical Nursing. Volume 2. New York: Wolters Kluwer

Gerogianni, G., Lianos, E., Polikandrioti, M., Grapsa, E. (2017). The role of socio-demographic factors in depression and anxiety of patients on hemodialysis: an observational cross-sectional study. International Urology and Nephrology.

Goldfarb-Rumyantzev, A.S., Koford, J.K., Baird, B.C., et al. (2006). Role of socioeconomic status in kidney transplant outcome. Clin J Am Soc Nephrol. 1:313322

Goyal, E., Chaudhury, S., Saldanha, D. (2018) Psychiatric comorbidity in patients undergoing hemodialysis. Ind Psychiatry J. 27(2): 206-212.

Iseki K. (2008). Gender differences in chronic kidney disease. Kidney Int. 74:415-417.
Jangkup, J.Y.K., Elim, C., Kandou, L.F.J. (2015). tingkat kecemasan pada pasien penyakit ginjal kronik (PGK) yang menjalani hemodialisis di BLU RSUP Prof. DR. R. D. Kandou Manado. Jurnal e-Clinic. 3(1), pp: 598-605

Juan Ng, H., Tan, W.J., Moopil, N., Stanton, N., Griva, K. (2014). Prevalence and patterns of depression and anxiety in hemodialysis patients: A 12-month prospective study on incident and prevalent populations. British Journal of Health

DOI:10.1111/bjhp.12106

Kamil, I., Agustina, R., Wahid, A. (2018). Gambaran tingkat kecemasan pasien gagal ginjal kronik yang menjalani hemodialisis di RSUD Ulin Banjarmasin. Dinamika Kesehatan. 2 (9). Pp: 366-377

Khan, A., Khan, A.H., Adnan, A.S., Sulaiman, S.A.S., Mushtaq, S. (2019). Prevalence and predictors of depression among hemodialysis patients: a prospective follow-up study. BMC Medic Health. 19 (531). $\mathrm{Pp}$ $1-13$ https://doi.org/10.1186/s12889-019-6796$\underline{z}$

Kinrys, G., Wygant, L.E. (2005). Anxiety disorders in women: does gender matter to treatment?. Revista Brasileira de Psiquiatria . 27(II):S43-50

Khattak, M., Sandhu, G.S., Desilva, R., et al. (2012). Association of education level with dialysis outcome. Hemodialysis International. 16:82-88

Kumar, V., Khandelia, V., Garg A. (2018). Depression and anxiety in patients with chronic kidney disease undergoing hemodialysis. Annals of Indian Psychiatry. 2 (2). 115-119

Kumar, T., Amalraj, A., Soundarajan, P., Abraham, G. (2003). Level of stress and coping abilities in patients on chronic hemodialysis and peritoneal dialysis. Indian J Nephrol. 13:89-91 
Kuniawati, A., Asikin, A. (2018). Gambaran tingkat pengetahuan penyakit ginjal dan terapi diet ginjal dan kualitas hidup pasien hemodialisis di Rumkital Dr. Ramelan Surabaya. Research Study; 125-135

Lewis, S.L., Dirksen, S.F., Heitkemper, M.M., et al. (2013). Medical Surgical Nursing; Assesment and Management of Clinical Problems. $10^{\text {th }}$ Ed. Velume 2. Mosby Elsevier

Lindgren, L. (2012). Emotional and Physiological Responses to Touch Massage. Sweden: Arkitektkopia

Polikandrioti, M., Koutelekos, I., Vasilopoulos, G., et al. (2017). Hemodialysis patients' information and associated characteristics. Mater Sociomed. 29(3): 182-187

Rector, N.A., Bourdeau, D., Kitchen, K., Massiah, L.D. (2008). Anxiety disorder an information guide. Canada: CAMH.

Riset Kesehatan Dasar. (2018). Riset Kesehatan Dasar; RISKESDAS. Jakarta: Balitbang Kemenkes RI

Sadock, B.S. (2015). Kaplan \& Sadock Synopsis of Psychiatry Behavioral Sciences/Clinical Psychiatry $11^{\text {th }}$ Edition. Philadelphia: Wolters Kluwer

Sherwood, L. (2016). Human Physiology From Cells To System, 10 $0^{\text {th }}$ Edition. Cengage Learning : USA. 